\title{
Tablet-based Field Work: \\ Opportunities and Challenges of Mobile Learning for Geography Education
}

\author{
Janis FÖGELE, Romy HOFMANN and Rainer MEHREN \\ FAU Erlangen-Nuremberg / Germany·janis.foegele@fau.de \\ This contribution was double-blind reviewed as full paper.
}

\begin{abstract}
Our daily lives are increasingly dominated by new technology. $90 \%$ of youngsters between the ages of 14-19 years use mobile phones and the internet several times a week and thus develop their own images of the world. A responsible school has to address this development as well as other current social developments.

For geography education in particular, field work is considered beneficial in developing students' spatial orientation. Experiencing the world "outside" extends many facts that one learns from the text book. Taking these preliminary considerations into account, this paper approaches tablet-based field work in geography classes by combining both beneficial and impeding factors of using technical devices in class. An example of tablet-based field work on a field trip to Berlin will be presented in order to show to what extent tablets can enhance geographic field work.
\end{abstract}

\section{Introduction}

The number of Tablet PCs purchased has increased rapidly since the introduction of Apple's iPad. In 2013, with 230 million exemplars sold, it was the first year worldwide that more tablets were sold than computers. In comparison to the preceding year, sales of mobile devices increased by $67.9 \%$. Tablet PCs, similarly to smartphones, have entered our daily lives and changed it profoundly. The foundations, both technically and infrastructurally, for the comprehensive use of tablets are laid, as well as developments in software and additional functions ("technological miniaturization", ARMSTRONG \& BENNETT 2005, 506). Mobile technology, in general, is used in various contexts. Museums and cities offer special thematic tours about/with new ways of networked communication; Tablet PCs play an important role in vocational training, and UNESCO continues its "Mobile Learning Week" in order to improve literacy and provide access to the field of mobile communication. The recent Horizon Report predicts a high adaption to new media within the next 12 months in educational establishments (JOHNSON et al. 2013, 4).

The JIM-survey, a study that explores youngsters' overall use of media and information in Germany, confirms their rather natural handling ("digital natives") of mobile phones and

Vogler, R., Car, A., Strobl, J. \& Griesebner, G. (Eds.) (2014): GI_Forum 2014. Geospatial Innovation for Society.

(C) Herbert Wichmann Verlag, VDE VERLAG GMBH, Berlin/Offenbach. ISBN 978-3-87907-545-4.

C ÖAW Verlag, Wien. eISBN 978-3-7001-7652-7, doi:10.1553/giscience2014s332. 
the internet. $90 \%$ of the youngsters use them several times a week (MEDIENPÄDAGOGISCHER FORSCHUNGSVERBUND SÜDWEST 2013, 11). By now, 14\% of German youngsters between 14 and 19 own a Tablet PC (ibid, 7). Within one year, the number of tablets has doubled. These figures indicate the youngsters' high individual relevance assigned to media in general, which can provide essential points of contact to use tablets at school by integrating the students' skills. At the same time, however, German schools are rather reluctant to incorporate mobile technology into the classroom (see the introduction of laptop computers), whereas in other parts of the world, they are part of daily school practice. Slowly schools are adapting to the new media (WEGE 2013). Pilot projects have been introduced which are accompanied scientifically. ${ }^{1}$

After formulating generally accepted benefits arising from the usage of Tablets PCs, as well as showing impediments to the implementation at school, the paper focuses on an example of tablet-based geographic field work that our team has been testing with students. Rather than aiming at generalisation, we plead for a step-by-step approach in order to further reduce the constraints to tablet-based (field) work at school.

\section{Potentials of Tablet PCs in Field Work}

Nowadays, information can be accessed ubiquitously, mostly due to the presence of technical devices and infrastructure. Based on this article's focus, it is central to distinguish between e(lectronic)-learning and $\mathbf{m}$ (obile)-learning. M-learning, as an extended form of elearning, describes the learning processes with smartphones, Tablet PCs, netbooks, or, scarcely, e-book-readers that do not necessarily depend on access to the internet (ibid, 14). Besides other differences, tablet PCs use so-called "apps" that are quickly available, some free of charge and easy to use. Mobile learning allows learning "along the way" with portable, mobile devices that provide instant and direct access to information and knowledge. Often they are also interconnected, yet spatially and temporally independent (ibid, 15). At the same time they also allow data to be augmented by location-based services using position signals (ibid). All these technical characteristics of mobile learning provide the foundation for field work in geography classes which can be used for the development of teaching arrangements to include added value for teachers and students.

In the literature, authors deal with the usage of tablets both in class and during outside activities and the reader is confronted with a dispersed variety of smaller case studies which evaluate possibilities (and difficulties) of new technologies in the school context ${ }^{2}$. Because of the fact that most studies are quite context-specific, it is not easy to derive general conclusions (RIEGER \& GAY 1997, 225). ${ }^{3}$ The focus is rather the identification and summary of

1 The following website provides an overview over German school projects working with tablets: http://www.tablet-in-der-schule.de/2013-05-30/tablet-schulen-in-deutschland.

2 In addition to the works cited in this article, THISSEN (2013) gives a summary of some (inter-) national studies from Australia, Finland, Austria, Germany etc. considering research questions, aims, methods and summaries. Their findings correspond with the potential of tablet-based work outlined in this article.

3 Most of the cases show that the usage of mobile devices has a positive effect on the students، motivation and their technical skills, whereas in general there are no definite records for better learning (STOLPMANN \& WeLLING 2008, 21). 
some key elements. Our attention is fixated on the pragmatic usage in the field and not so much on comparing technical conditions (see for example CLEGG et al. 2006). Depending on the aim of tablet-based (field) work, its potentials vary. From a commonplace point of view in terms of comparing tablet-based and conventional classes (field work in particular), the benefits of Tablets are pragmatic handling and operation - Tablet PCs integrate many devices and functions in one:

- $\quad$ Operation | trying out, intuitive usage

- Production | generating and synthesising data, creative and innovative problem-solving

- Information and research $\mid$ differentiation through extra information

- Communication | collaboration, distribution

- Presentation and visualisation | distribution with no extra devices (pens etc.) needed

Based on these assumptions and in reference to the concept of spatial citizenship, a model (Fig. 1) is proposed that further integrates three basic media competences (BAACKE 1997). They are supplemented by the national standards for geography education (DGfG 2012).

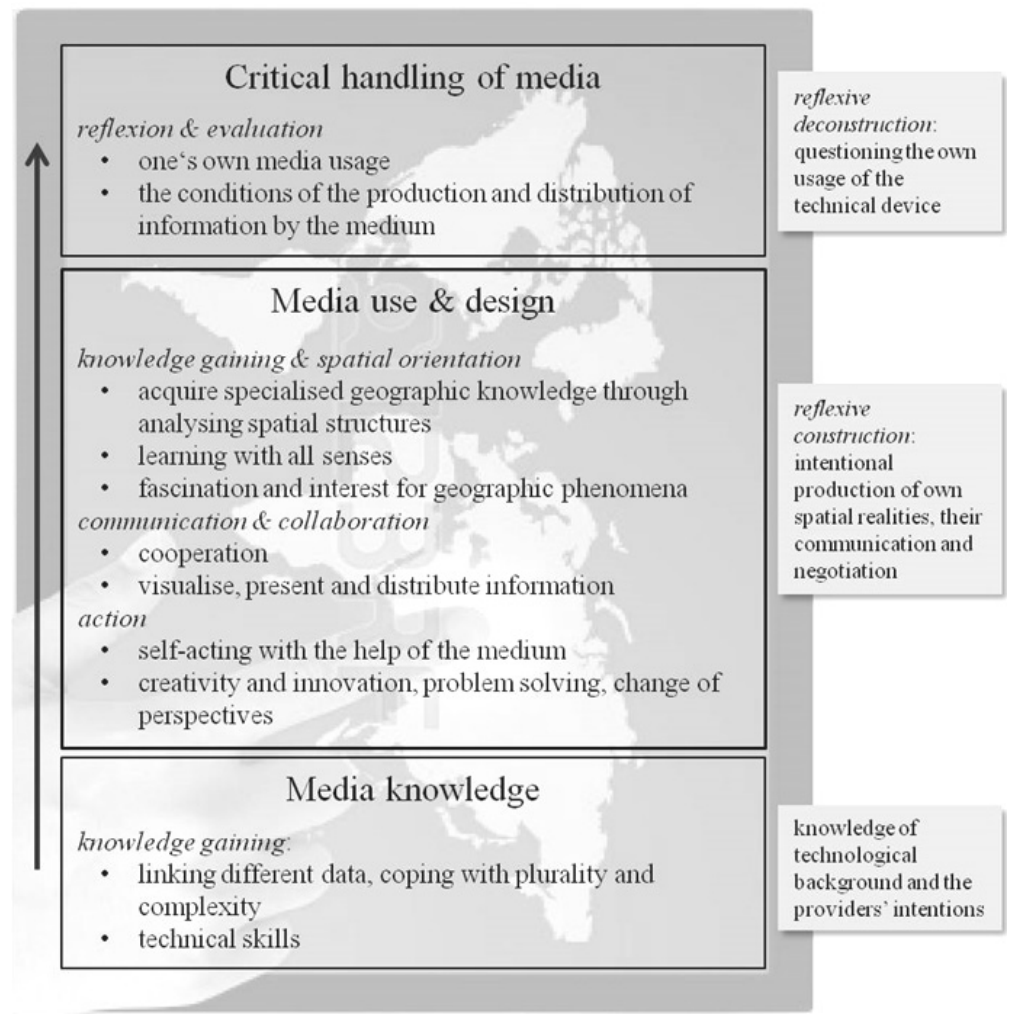

Fig.1: Modelling the benefits of tablet-based field work, based on the concept of spatial citizenship (GRYL \& JEKEL 2013, 256). Own illustration. 
The main potential of the application of Tablet PCs in school so far is seen in the intuitive usage and corresponding positive feelings that allow free and convenient work with the device (QUINN 2013, 93). Students are given the chance to "incorporate personal experiences" (ibid, 87) into their learning processes, so that school context and individual experiences are linked. This may be one reason for increased motivation when working with Tablet PCs. Involvement in tablet-based courses was estimated higher by the students (STEWART et al. 2011), whereas motivation decreases after a certain time of use (STOLPMANN \& WELLING 2008, 83f). In general, collaboration between students is more intense and "staff interventions" (JARVIS et al. 2013, 85) are facilitated. Furthermore, the ability to generate interest and fascination for different (geographic) phenomena are discussed. "Affective factors play a strong role (both positive and negative) in harnessing technology for learning" (JONES et al. 2006, 15), for both students and teachers. For example, students praise "freedom and independence" (JARVIS et al. 2013, 85) while doing their tasks without the teacher's presence (ibid, 86), which in turn encourages free communication and "confidence to speak out" (ibid, 85). Students do not feel "taught" by their teacher and they work on their own (LUDWIG et al. 2011, 14).

In order to measure the benefits of tablet-based field work it seems necessary to distinguish between learning processes and learning outcomes. In their study in the field of engineering, HoJJATIE et al. (2008) state that students' learning outcomes improved when using a Tablet PC. If we understand learning as a self-directed, active and constructive, situated and social process in tablet-based work, the learners are given special opportunity to articulate and reflect on their learning processes and outcomes as well (STOLPMANN \& WELLING 2008, 10). In addition, this kind of work fosters students' non-linear thinking. They are "building multistructural understandings" (JARVIS et al. 2013, 85) since they need to combine different data and information that the Tablet PC and their surroundings offer. Students' learning reached "reflective and on occasion sometimes abstract, integrated levels" (ibid, 89), as they used reflective field diaries (ibid, 82). Besides, learning outcomes and even accuracy of work are evaluated as better (STEWART et al. 2011). This includes technology skills and the use of maps as well (ibid).

\section{$3 \quad$... and the Difficulties in School Life}

Until now there are no big quantitative studies regarding the use of Tablet PCs and mobile learning in school-related field work. To analyse significant difficulties in mobile learning using different GI(S)-applications we refer to a larger empirical study (see HöHNLE et al. 2011). Teachers had to rate 21 items of possible impediments to the usage of GI(S)-devices in geography lessons on a five-level Likert-like scale ranging from 5 (= strongly agree) to 1 (= strongly disagree). The items of the questionnaire were developed based on studies by KERSKI (2003) and BAKER et al. (2009). Most of the items used in these studies were adopted and some additional ones added based on further literature from the field and nation-specific features. The self-administered questionnaire could be filled in at teacher training activities for secondary school teachers throughout Germany and via an online questionnaire, which resulted in a sample of 410 teachers. An overview to the most important impediments is presented in HöHNLE et al. (2011). 
Afterwards, these empirical results were presented to groups of teachers. In group discussions, they should develop concepts suitable to overcoming these impediments. The results will be considered below and complemented with some issues discussed in Chapter 2 concerning an effective development and practice of Tablet PCs in the context of mobile learning.

The following criteria are supposed to be useful for an effective usage of GI(S)-devices and tablets in m-learning:

1. Reducing technical challenges: Teachers are often overcharged due to the complexity of common GI(S)-applications. They express their need for professional support (stepby-step instruction) to handle the GI-software - although they only need some particular operations. Since Tablet PCs and their applications are rather easy to use (STEWART et al. 2001), this is a big advantage of mobile learning in geography lessons.

2. Time constraints: The limitation of conventional class time frames (in Germany: 45 minutes) challenges the usage of GI(S)-devices. That is why teachers demand for small teaching units which they can integrate into their classes. Tablet PCs and corresponding apps are quickly available and require short training time only.

3. Freeware: Teachers prefer freeware or low-cost software to use at their home office in order to accelerate the training period and to get more time to prepare their lessons using GI(S)-applications. Tablet PCs and apps are easily available for teachers and students and can be used beyond the teaching time.

4. Compatibility with the curriculum: In order not to perceive the usage of GI(S) and mobile learning as additional content (and thus as additional workload), those case studies and examples being developed and presented in journals or teacher trainings must necessarily be curriculum-related.

5. Spatial transferability: Examples have to be elaborated that are transferable to other local contexts and circumstances (e.g. mapping of the retail sector in a city).

6. Evident benefit: Teachers who perceive the use of GI(S) and Tablet PCs in their geography lessons as an additional value in contrast to common (analogue) maps will use it more often. Therefore units for the implementation of Tablet PCs in field work should use these devices to collect data from different sources (not only as a digital map application), to analyse data etc.

Further insights of empirical studies can be added to this compilation:

7. Minds-on instead of hands-on: TESCH \& DUIT (2004) showed positive correlations between total time of experimentation, including preparation and postprocessings, and student achievements in Physics classes. Considering the mere period of experimentation only, no correlation could be found. Thus, experimentation - GI(S) usage and Tablet PC usage likewise - should include more than only hands-on activities (according to a step-by-step instruction). Important cognitive activities (minds-on) have to be performed when planning and reflecting on one's own line of work. Tablet PCs should be used thoroughly as a tool to explore geographical issues. Therefore a problem-oriented approach seems suitable.

8. Avoiding training time on technical devices in class: FUCHS \& WÖßMANN (2005) investigated effects of computer usage on student performance in the context of PISA. They could show that students performed better as a result of moderate computer and internet usage (up to several times a month) than was the case without computer and internet in class. However, if the usage increases even more, this leads to reduced stu- 
dent performance, falling even below the level of students who are not using the computer and internet at all. This could be explained by the displacement of potentially more effective, alternative teaching forms by the dominant usage of computers. Therefore, computer and internet as well as Tablet PC and mobile learning should be used moderately. Due to their usability, Tablet PCs and apps require little training time.

9. Competence-based geography lessons: MEHREN \& UPHUES (2010) define six criteria for competence-based geography lessons. Concerning GI(S) related mobile learning, the following criteria should be considered. Creating a "culture of tasks" and problems in geography lessons that address students, evoke cognitive activities, and facilitate metacognitive processes. Knowledge itself does not possess intrinsic value; it serves functional interests in order to solve challenging problems (RICHTER 2007, 4). These criteria can be used to plan geography lessons that support the usage of GI(S) and m-learning to deal with complex issues as a means of facilitating conceptual thinking (WILDT 2009, 19).

\section{An Example of Tablet-based Field Work: Gentrification in the Centre of Berlin}

The findings reported above lead to some suggestions for the utilisation of tablets in geographic field work. It is not the aim to use every resource the tablets offer, because it should be used moderately. As a first step we propose an implementation of tablets with low technical obstacles. In the following we conceptualise one possibility to work with tablets on site by avoiding the impediments mentioned above and exploiting the opportunities expected of mobile learning.

Curricular context | Gentrification at Prenzlauer Berg, Berlin: The example of field work deals with the process of gentrification at Prenzlauer Berg in Berlin, Germany. This quarter ("Kiez") is an example of gentrification in a rather advanced stage. Hardly destroyed after the Second World War, the quarter got "relocated" into a peripheral position in East Berlin. Thus, little restoration took place during East German times. After the fall of the Berlin Wall, Prenzlauer Berg is now close to the city centre. Subsequently processes like upgrading and displacement of residents are taking place. The values of the houses are rising as a result of the restoration of the physical structure and this leads to rent increases. Only $17 \%$ of the ancestral residents of 1993 are located in the quarter today (FASSMANN 2009, 167).

In contrast to the prototypical process in which pioneers like artists and students enter the neighbourhoods because they are affordable, leading to a rise in the quarter's attractiveness, the onset of gentrification in Prenzlauer Berg was politically induced. "Stadtumbau Ost", a reconstruction programme, aims at the improvement of (Wilhelminian) accommodation (HÄUßERMANN 2004, 53). Incoming residents, affluent gentrifiers like media workers, replace the gentrified. The new socio-economic composition of Prenzlauer Berg is apparent in the cityscape, for instance due to child-friendly infrastructure ("babyccino") (see DÖRFLER 2010, 277). During field work, students are dealing with upgrading processes concerning the physical, social, functional and symbolic structure, as dimensions of gentrification (see KRAJEWSKI 2006, 61ff). The issue of the presented field work is well integrated in the geography curriculum and can be transferred to different local conditions. 


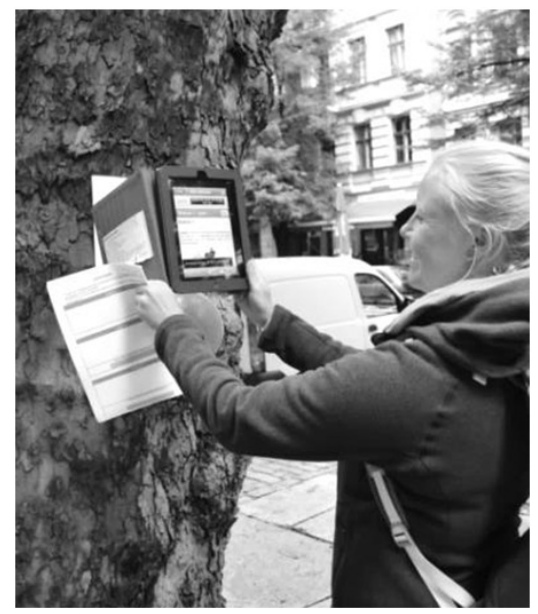

Fig. 2:

Students working in the field (Prenzlauer Berg)

Structure of the field work: The field work was designed in due consideration of the eight criteria for good excursions developed by HEMMER \& UPHUES (2009) and is linked to the criteria of competency based Geography lessons mentioned above (MEHREN \& UPHUES 2010). They are important to successfully use the tablets as well. The only apps being used are the Google Maps-function, a QR-Code-reader and a webbrowser. Technical obstacles are thus minimised. The tools are free and quickly available, the familiarisation with the software happens intuitively (avoiding training time). The tablet's camera scans the QRCode located at particular spots in the quarter. In this way, students get access to a website containing information and tasks for every workstation. The information from the Tablet PC can be used reliably as it is not perishable like physical phenoma (f.e. advertisement, houses torn down etc.). The use of a map as a foundation helps the students to orientate themselves. The possibility to connect further data sets creates additional benefit in comparison to analogue maps (evident benefit). Furthermore, the students acquire more specified knowledge about media by using it actively (media knowledge, see Fig. 1). The results of every workstation are recorded on a worksheet that is used for the entire field work ("guiding medium"). After the work on site the students receive a new coordinate using the website. Students can navigate using the Tablet PC (GPS capability) to get to the next workstation.

Course of the field work: The single workstations are presented in Table 1. Afterwards we take a closer look at one location in order address the usage of the Tablet PC in particular.

Tab. 1: Field work at Prenzlauer Berg - working at different locations

\begin{tabular}{|l|l|l|}
\hline Location & Thematic and methodical key aspects & Media \\
\hline $\begin{array}{l}\text { Prologue } \\
\text { "Marienburger } \\
\text { Street" }\end{array}$ & $\begin{array}{l}\text { Tram station: Students carefully observe the environment and gather } \\
\text { first impressions on their way to the first location }\end{array}$ & $\begin{array}{l}\text { blank paper (M1), } \\
\text { Wocation 1 }\end{array}$ \\
\hline $\begin{array}{l}\text { Problematisation Street } \\
\text { Teacher poses mystery question: “Why are the residents of Prenzlauer } \\
\text { bags?" and students formulate first ideas that are assembled on the } \\
\text { poster }\end{array}$ & pend, wearing an singlet and carrying plastic \\
\hline
\end{tabular}




\begin{tabular}{|c|c|c|}
\hline & $\begin{array}{l}\text { Technical introduction } \\
\text { The teacher presents the structure of the field work, teaching arrange- } \\
\text { ment, and corresponding rules; he explains how to use the Tablet PC } \\
\text { and QR-Codes, and distributes the guiding medium } \\
\text { The students are divided into five groups and get the respective QR- } \\
\text { Codes }\end{array}$ & $\begin{array}{l}\text { Tablet PCs, guiding } \\
\text { medium (M2) } \\
\text { QR-Codes (M3) }\end{array}$ \\
\hline \multicolumn{3}{|c|}{$\begin{array}{l}\text { In the following, the students work on stations A-E in rotating order. Every group starts at a different location } \\
(\rightarrow \mathrm{M} 3 \text { ). By scanning the QR-Code at the locations, the groups get the material for their work. Potentials of } \\
\text { tablet-based field work (see Fig. 1): media use \& design: self-acting, knowledge gathering, spatial orientation; } \\
\text { media knowledge: knowledge gaining }\end{array}$} \\
\hline $\begin{array}{l}\text { Location 2A } \\
3 \text { Husemann } \\
\text { Street }\end{array}$ & $\begin{array}{l}\text { 2A - Pre-conditions and process of gentrification } \\
\text { Students get to know the pre-conditions for this process by using } \\
\text { different material (changed geographic location, creative class); stu- } \\
\text { dents arrange the different phases of gentrification in the correct order }\end{array}$ & $\begin{array}{l}\text { Tablet PCs, guiding } \\
\text { medium (M2), } \\
\text { internet page }\end{array}$ \\
\hline $\begin{array}{l}\text { Location 2B } \\
74 \text { Kollwitz } \\
\text { Street }\end{array}$ & $\begin{array}{l}\text { 2B - Structural upgrading } \\
\text { Students compare photographs from the } 1990 \text { s with today's situation } \\
\text { and consider structural measures } \\
\text { Students analyse the situation of the property market by using statistics } \\
\text { and discuss ways to prevent luxury restructuring }\end{array}$ & $\begin{array}{l}\text { Tablet PCs, guiding } \\
\text { medium (M2), } \\
\text { internet page }\end{array}$ \\
\hline $\begin{array}{l}\text { Location 2C } \\
\text { Kollwitz Square }\end{array}$ & $\begin{array}{l}\text { 2C-Social upgrading } \\
\text { Students cartoon a "typical" inhabitant of Prenzlauer Berg from their } \\
\text { own point of view } \\
\text { Students assign different social types to Prenzlauer Berg } \\
\text { Students analyse statistics about the social composition and compare } \\
\text { them with their assumptions } \\
\text { Students elaborate pros and cons of social upgrading by listening to an } \\
\text { interview }\end{array}$ & $\begin{array}{l}\text { Tablet PCs, guiding } \\
\text { medium (M2), } \\
\text { internet page }\end{array}$ \\
\hline $\begin{array}{l}\text { Location 2D } \\
11 \text { Sredzk Street }\end{array}$ & $\begin{array}{l}\text { 2D - Symbolic upgrading } \\
\text { Students compare media reports about Prenzlauer Berg in the course of } \\
\text { time } \\
\text { Students formulate spontaneous associations about "Kulturbrauerei" } \\
\text { and afterwards read some information about it } \\
\text { Students ask passengers to complete the sentence "For me Prenzlauer } \\
\text { Berg is..." }\end{array}$ & $\begin{array}{l}\text { Tablet PCs, guiding } \\
\text { medium (M2), } \\
\text { internet page }\end{array}$ \\
\hline $\begin{array}{l}\text { Location 2E } \\
\text { Wörther Street }\end{array}$ & $\begin{array}{l}\text { 2E - Functional upgrading } \\
\text { Students go to the "Kochhaus" and compare its marketing concept to a } \\
\text { conventional supermarket } \\
\text { Students characterise the development of the gastronomy sector from } \\
\text { the } 1990 \text { s to today by using maps } \\
\text { Students read a critical report on functional upgrading and discuss its } \\
\text { contents }\end{array}$ & $\begin{array}{l}\text { Tablet PCs, guiding } \\
\text { medium (M2), } \\
\text { internet page }\end{array}$ \\
\hline \multicolumn{3}{|c|}{$\begin{array}{l}\text { After finishing all workstations, the groups meet at the "Tuntenhaus"- the corresponding information to get there } \\
\text { is provided by the geodata in the guiding medium (M2). }\end{array}$} \\
\hline $\begin{array}{l}\text { Location } 3 \\
\text { "Tuntenhaus", } 96 \\
\text { Kastanien Street }\end{array}$ & $\begin{array}{l}\text { Evaluation \& conclusion } \\
\text { The groups compare their solutions with the teacher's ideas and the } \\
\text { term "gentrification" is introduced } \\
\text { The mystery question from the beginning is answered } \\
\text { Pros and cons of gentrification } \\
\text { Teacher shortly presents the "Tuntenhaus" - a homo- and transsexual } \\
\text { housing project which is totally different compared to the local hous- } \\
\text { ing conditions - and distributes the "anti-gentrification-kit" to the } \\
\text { students } \\
\text { Students consider the process of gentrification either rather positive or } \\
\text { rather negative and position themselves forming an individual figure } \\
\text { Both groups (in favour and against) face each other and discuss their } \\
\text { opinions in an "English debate" }\end{array}$ & $\begin{array}{l}\text { guiding medium } \\
\text { (M2), ideal solution } \\
\text { (M5) }\end{array}$ \\
\hline
\end{tabular}


Location C: The social changes that have happened in Prenzlauer Berg can best be recognised by considering people's appearance and daily routines. Students work on this at location C. They first go to the playground in the midst of Kollwitz Square because many young people and families meet there. After scanning the QR-Code, the students are asked to have a guess about the "typical" inhabitant of Prenzlauer Berg. Different groups of people are visualised stereotypically on the Tablet PC (critical handling of media: reflexion \& evaluation, see Fig. 1). After observing the people there, the students should cartoon their "typical" inhabitant. They use the device as a drawing block; free apps are available for this. Their results can afterwards be distributed and compared easily (media use \& design: communication \& collaboration: visualise, present and distribute information). With the aid of tables and further information about the social structure (age, immigration) of Prenzlauer Berg, the students should then recognise that mainly young and wealthy people live there, often families (media knowledge: technical skills, linking different data). They can now decide if their first presumptions about the "typical people" were right. In order to get to know the negative parts of gentrification, the students listen to an interview conducted with an elderly woman who has lived in Prenzlauer Berg all of her life and was displaced by these processes not long ago. The woman mentions pros and cons of the development. Thus, the students are encouraged to critically look at gentrification and come up with their own opinion. Besides other opportunities mentioned in the introduction to the field trip, like easy software familiarisation and low technical obstacles, Location $\mathrm{C}$ offers (like each station in the field work) both minds-on and hands-on activities. In summary, this short overview of Location $\mathrm{C}$ and the exemplary indications shown in Table 1 illustrate the potential of this tablet-based field work teaching arrangement.

\section{Conclusion and Outlook}

Despite their present rise in popularity, the use of Tablet PCs will not improve geography lessons at once. From our example shown above, students mainly report technical impediments, such as bad video quality or choosing another QR-Code reader. Problems often arise within the "human-behavior domain" (ARMSTRONG \& BENNETT 2005, 513): students might be inattentive, be cheating more, and use the device for activities other than academic purposes. Finally, space-boundaries still exist which Tablet PCs will not dissolve. If students encounter problems during their work they might need help that the device cannot provide (FINKELSTEIN et al. 2013). However, m-learning presents didactically valuable approaches for school contexts. Using a Tablet PC as shown exemplarily proves to be reasonable because it complies with the criteria laid down in Chapter 3. Students are to actively combine data (tables, pictures, audio files) with information from the field which fosters their "metalearning" (QUINN 2013, 91). As the focus of field work is less on "hard" learning outcomes but rather on the students' ability to use data for spatial reasoning, a Tablet PC proves to be vital in the provision of information in addition to the facts the students experience on site. Since students are working with the device, they get acquainted with it and develop own strategies for problem-solving ("minds on"). A Tablet PC does not, however, replace other working methods in class or in the field. A moderate use of the device seems to be the way to go here. The potentials do indeed show, as illustrated in the model (Fig. 1). Students further state that they are motivated more when using the Tablet PC; they experience a better feeling of group membership and highly praise the freedom of work and related 
learning strategies. Implementing Tablet PCs in geographic field work should necessarily start by the teachers' disposition to their usage as s/he is the chokepoint (NORRIS \& SOLOWAY 2013, 115f; LUDWIG 2013, 85). After all, learning results and atmosphere still heavily depend on the teacher, for example preparation and own technical skills (ADAMS \& HAYES 2009, 1; see HATTIE 2009, 109). New technology requires new pedagogic approaches that position students at the centre of the subject (NORRIS \& SOLOWAY 2013, 115; RIEGER \& GAY 1997, 225). In addition, competence-oriented planning of teaching units is vital because it fosters students' conceptual thinking and active involvement in the work process. Insights from the field that serve as good examples are a starting point, but have to be consolidated and expanded. Benefits and successful achievements of both the students' and teachers' work will encourage further commitment to m-learning.

\section{References}

AdAMs, N. \& HAYES, C. (2009), Does Teaching with a Tablet PC Enhance the Teaching Experience and Provide Greater Flexibility? Monash Education.

http://www.monash.edu.au/eeducation/assets/documents/atiec/2009/2009atiecnadineadams-clintonhayes.pdf, (06.04.2014).

Armstrong, M. P. \& BennetT, D. A. (2005), A Manifesto on Mobile Computing in Geographic Education. The Professional Geographer, 57 (4), 506-515.

BAACKE, D. (1997), Medienpädagogik. Niemeyer.

Baker, T. R., Palmer, A. M. \& Kerski, J .J. (2009), A National Survey to Examine Teacher Professional Development and Implementation of Desktop GIS. Journal of Geography, 108, 174-185.

Clegg, P., Bruciatelli, L., Domingos, F., Jones, R. R., De Donatis, M. \& Wilson, R. W. (2006), Digital geological mapping with tablet PC and PDA: A comparison. Computers \& Geosciences, 32, 1682-1698.

DE WITT, C. (2013), Vom E-Learning zum Mobile Learning - wie Smartphones und Tablet PCs Lernen und Arbeit verbinden. In: DE WITT, C. \& SiEBER, A. (Eds.), Mobile Learning. Springer, 13-26.

DGFG (2012), Bildungsstandards im Fach Geographie für den Mittleren Schulabschluss mit Aufgabenbeispielen. Selbstverlag Deutsche Gesellschaft für Geographie.

DöRfLER, T. (2010), Gentrification in Prenzlauer Berg. Milieuwandel eines Berliner Sozialraums seit 1989. Bielefeld, $332 \mathrm{p}$.

FASSMANN, H. (2009), Stadtgeographie I. Braunschweig, 256 p.

Finkelstein, A. B. A., Winer, L., Buddle, C. \& ERnST, C. (2013), Tablets in the Forest: Mobile Technology for Inquiry-Based Learning.

http://www.educause.edu/ero/article/tablets-forest-mobile-technology-inquiry-basedlearning (06.04.2014).

FRIEDRICH, K. (2000), Gentrifizierung. Theoretische Ansätze und Anwendung auf Städte in den neuen Ländern. Geographische Rundschau, 52 (7-8), 34-39.

Fuchs, T. \& WÖßMANN, L. (2005), Computer können das Lernen behindern. ifo Schnelldienst, 58 (18), 16-23.

GRYL, I. \& JEKEL, T. (2013), "Spatial citizenship“. In BÖHN, D. (Ed.), Wörterbuch der Geographiedidaktik. Westermann, 256-257. 
HAtтiE, J. (2009), Visible Learning. A synthesis of over 800 meta-analyses relating to achievement. Taylor \& Francis, 392 p.

HÄUßERMANN, H. (2004), Prenzlauer Berg - eine Erfolgsgeschichte? DISP, 156, 53.

HeMmeR, M. \& UpHUES, R. (2009), Zwischen passiver Rezeption und aktiver Konstruktion. Varianten der Standortarbeit aufgezeigt am Beispiel der Großwohnsiedlung BerlinMarzahn. In DickEL, M. \& GLASZE, G. (Eds.), Vielperspektivität und Teilnehmerzentrierung. Richtungsweiser der Exkursionsdidaktik. LIT, 39-51.

HöHnle, S., Schubert, J. C. \& Uphues, R. (2011), Barriers to GI(S) Use in Schools. A Comparison of International Empirical Results. In: JEKEL, T., Koller, A., DONERT, K. \& Vogler, R. (Eds.), Learning with Geoinformation V. Berlin/Offenbach, Wichmann, 124-134.

Hojjatie, B., Hooshmand, H., Leader, L., BreviK, E. \& Groszos, M. (2008), How can the use of tablet PCs in Science and Engineering improve teaching and learning? In: Reed, R. H., Berque, D. A. \& Prey, J. (Eds.), The Impact of Tablet PCs and Penbased Technology on Education: Evidence and Outcomes. Purdue University Press, 4753.

Jarvis, C. H., Dickie, J. \& Brown, G. (2013), Going mobile. Perspectives on aligning learning and teaching in geography. Journal of Geography in Higher Education, 37 (1), 76-91.

Johnson, L., Adams Becker, S., Cummins, M., Estrada, V., Freeman, A. \& Ludgate, H. (2013), NMC Horizon Report: 2013 Higher Education. German Edition (translation by Helga Bechmann). Austin, Texas: The New Media Consortium, $50 \mathrm{p}$. www.nmc.org/pdf/2013-horizon-report-HE-DE.pdf, (06.04.2014).

Jones, A., ISSROFF, K. \& SCANLON, E. (2006), Affective factors on learning with mobile devices. In SHARPLES, M. (Ed.), Big Issues in Mobile Learning. Report of a Workshop by the Kaleidoscope Network of Excellence Mobile Learning Initiative. University of Nottingham, 15-20.

KERSKI, J. (2003), The Implementation and Effectiveness of Geographic Information Systems Technology and Methods in Secondary Education. Journal of Geography, 102, 128-137.

KinNIBURGH, J.C. (2008), An Investigation of the Impediments to Using Geographical Information Systems to Enhance Teaching and Learning in Mandatory Stage 5 Geography in New South Wales. Geographical Education, 21, 20-38.

KRAJEWSKI, C. (2006), Urbane Transformationsprozesse in zentrumsnahen Stadtquartieren - Gentrifizierung und innere Differenzierung am Beispiel der Spandauer Vorstadt und der Rosenthaler Vorstadt in Berlin. WWU Münster, 546 p.

LuDWIG, L. (2013), Schulisches Lehren und Lernen mit Tablets - Standortbestimmung, Bedingungsfaktoren, Mehrwert. LudwiG, L., Narr, K., Frank, S. \& Staemmler, D. (Eds.), Lernen in der digitalen Gesellschaft - offen, vernetzt, integrativ, 81-88.

Ludwig, L., MAYRBerger, K. \& Weidmann, A. (2011), Einsatz personalisierter iPads im Unterricht aus Perspektive der Schülerinnen und Schüler. In: RoHLAND, H., KIENLE, A. \& FRIEDRICH, S. (Eds.), DelFi 2011, 7-17.

MEdienPÄDAGOGISCHER ForSCHUNGSVERBUND SÜDWEST (2013), JIM-Studie 2013. Jugend, Information, (Multi-) Media. Stuttgart, $72 \mathrm{p}$.

Mehren, M. \& Uphues, R. (2010), Gute Theorie ist praktisch - Kompetenzorientiert Unterrichten im Fach Geographie. Terrasse, 3, 8-12. 
Norris, C. A. \& Soloway, E. M. (2013), Substantive Educational Changes is in the Palm of our Children's Hands. In. Berge, Z. L. \& MuILENBURG, L.Y. (Eds.), Handbook of Mobile Learning. Routledge, 109-118.

Quinn, C. N. (2013), A Future for M-Learning. In: Berge, Z. L. \& MuilenburG, L. Y. (Eds.), Handbook of Mobile Learning. Routledge, 82-94.

RICHER, R. (2007), Biologieunterricht im Umbruch. Unterricht Biologie, 328, 2-7.

RIEGER, R. \& GAY, G. (1997), Using mobile computing to enhance field study. In: HALL, R., Miyake, N. \& Enyedy, N. (Eds.), Proceedings of the 2nd International Conference on Computer Support for Collaborative Learning, CSCL '97, Toronto, Ontario, Canada. International Society of the Learning Sciences, 218-226.

Stewart, M., Clark, J. J., Donald, J. W. \& VAn CAMP, K. (2011), The Educational Potential of Mobile Computing in the Field. Educause Quarterly.

http://www.educause.edu/ero/article/educational-potential-mobile-computing-field, (06.04.2014).

Stolpmann, B. E. \& Welling, S. (2008), Integration von Tablet PCs im Rahmen des Medieneinsatzes einer gymnasialen Oberstufe. Endbericht. Institut für Informationsmanagement Bremen $\mathrm{GmbH}, 121 \mathrm{p}$.

Tesch, M. \& DuIT, R. (2004), Experimentieren im Physikunterricht - Ergebnisse einer Videostudie. Zeitschrift für Didaktik der Naturwissenschaften, 10, 51-69.

THISSEN, F. (2013), Mobiles Lernen in der Schule. www.frank-thissen.de/ibook_gut.pdf (06.04.2014).

WeGE, B. (2013), Der Neue im Klassenzimmer. ZEIT Online (18.07.2013).

http://www.zeit.de/2013/30/digitaler-unterricht-tablet-pcs, (06.04.2014).

WILDT, M. (2009), Diagnostik vom Nutzen her denken! Lernchancen, 69/70, 14-19. 